
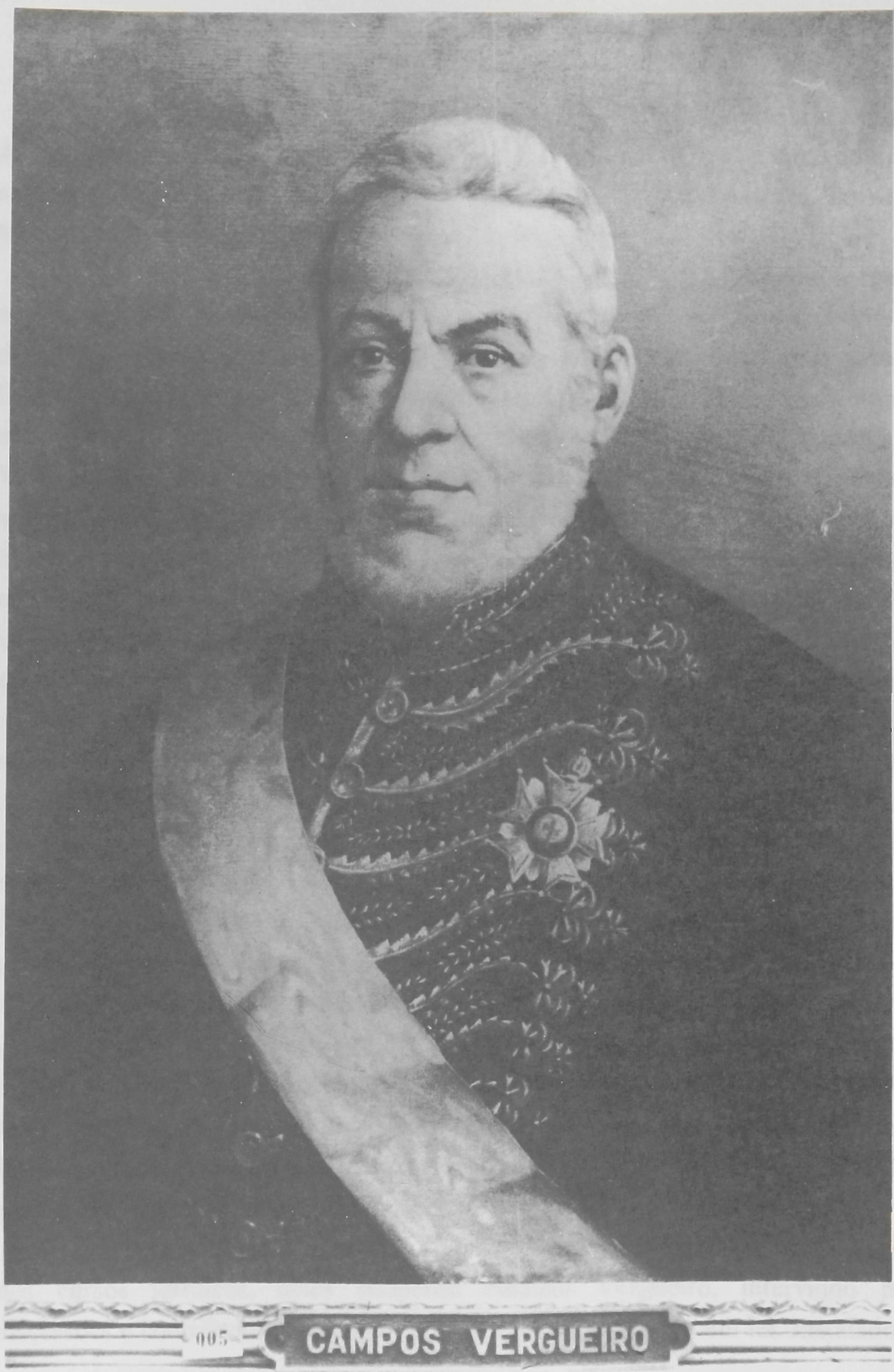



\section{Conselheiro Dr. NICOLAU PEREIRA DE CAMPOS VERGUEIRO (1837-1842)}

Filho do Dr. Luiz Bernardo Vergueiro e de D. Clara Maria Borges de Campos, nasceu aos 20 de dezembro de 1778, em Val de Porca, antigamente comarca de Chacin, hoje Macedo de Cavalleiros, na província de Traz-osMontes, bispado e comarca de Bragança, em Portugal.

Feitos os estudos menores no Real Colégio das Artes, com assento na Universidade de Coimbra, matriculou-se nesta universidade aos 5 de outubro de 1876, doutorando-se em leis a 11 de julho de 1801. Formado, veio para o Brasil, em 1803, fixando-se em São Paulo. Aqui, em 1804, contraiu matrimônio com D. Maria Angélica de Vasconcellos, filha do capitão José de Andrade e Vasconcellos e de D. Anna Eufrosina de Cerqueira Câmara. No foro paulistano militou como advogado ao lado dos doutores Manoel Euphrasio de Azevedo Marques, José Arouche de Toledo Rendon e Manoel Joaquim Ornellas, que eram, então, os únicos advogados em São Paulo. Advogou até 1815. Foi juiz das sesmarias, até 1816, quando se retirou para Piracicaba a fim de dirigir os engenhos que ali fundou de sociedade com o brigadeiro Luiz Antonio de Souza. A partir de então sua atividade se desdobrou, prestando ao nosso país os mais relevantes serviços. Depois de ter sido promotor de resíduos (1806) e juiz ordinário (1811), foi nomeado vereador da Câmara Municipal de São Paulo (1813), membro do governo provisório da província de São Paulo (1821), deputado à Constituinte Portuguesa (1822), deputado à Constituinte Brasileira (1823), deputado geral por São Paulo (1826 a 1828), senador por Minas Gerais (1828 a 1859), membro do Conselho do Governo de São Paulo (1826 a 1829 e 1830 a 1833), membro da Regência Provisória Trina (1831), ministro do Império (1832), ministro da Fazenda (1832), deputado à Assembléia Provincial de São Paulo (1835 a 1847), presidente da Assembléia Legislativa de São Paulo (1835 a 1837), grã-cruz da Imperial Ordem do Cruzeiro (1841), gentil homem da Casa Imperial (1846), ministro da Justiça (1847), ministro do Império (1847), presidente e membro do Conselho de S. M. o Imperador.

Desde que surgiram os projetos parlamentares relativos à fundação dos cursos jurídicos, neles cooperou Nicolau Vergueiro, intervindo nas discussões e contribuindo para que o projeto fosse convertido em lei. Instalado o 
Curso Jurídico de São Paulo, quando no governo, várias medidas sugeriu para o seu desenvolvimento, como a criação da cadeira de direito civil administrativo.

Foi nomeado diretor do Curso Jurídico, por decreto de 28 de janeiro de 1837, do regente Feijó. Tomou posse em 13 de março do mesmo ano e exerceu o cargo durante cinco anos, do qual foi demitido por decreto de 10 de fevereiro de 1842 .

Faleceu no Rio de Janeiro aos 18 de setembro de 1859. 